Document downloaded from:

http://hdl.handle.net/10251/46526

This paper must be cited as:

Oviedo-Haito, R.; Jiménez Ayala, J.; Cardoso, F.; Pellicer Armiñana, E. (2014). Survival Factors for Subcontractors in Economic Downturns. Journal of Construction Engineering and Management. 140(3):40130501-40130510. doi:10.1061/(ASCE)CO.19437862.0000811 .

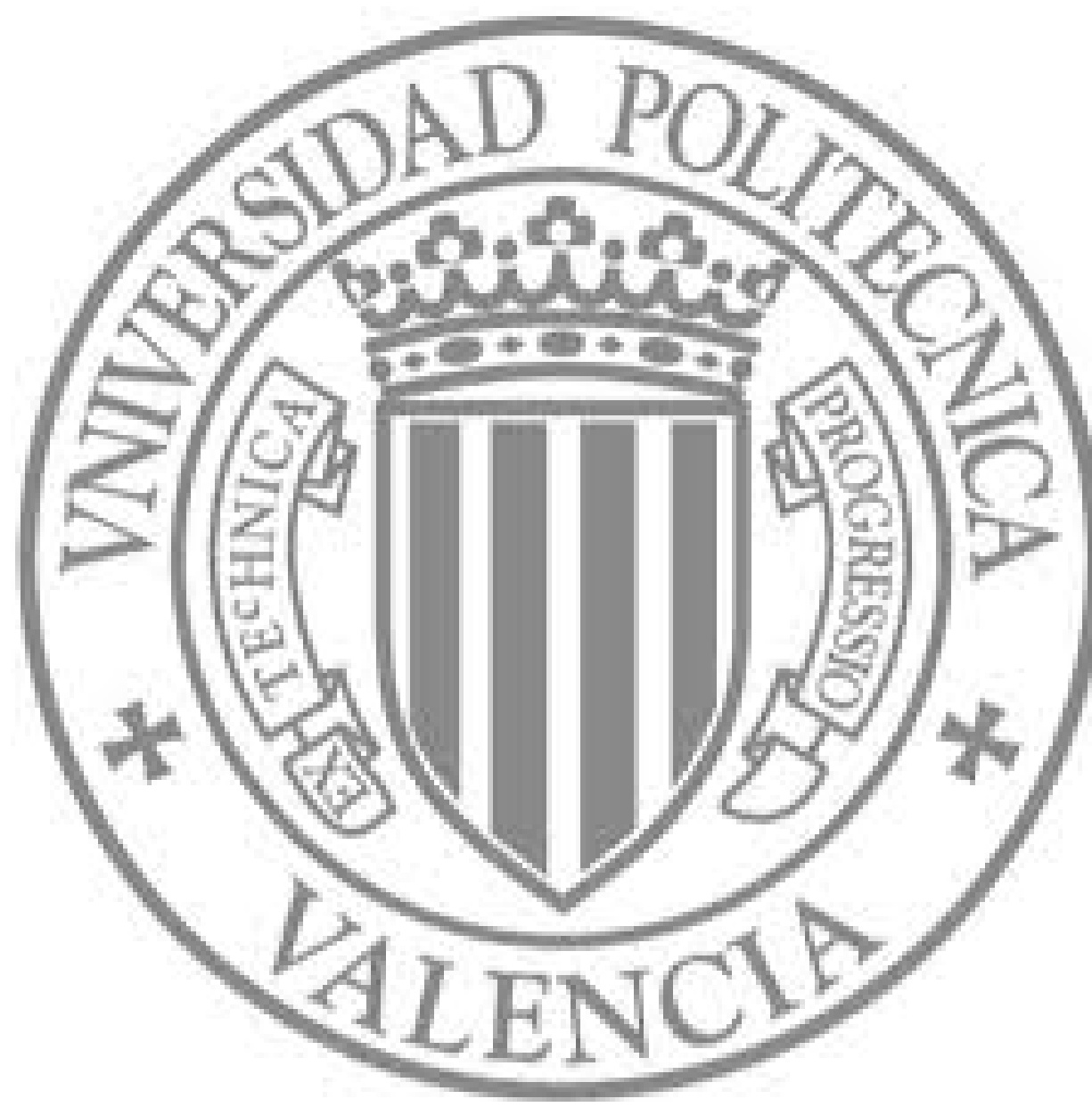

The final publication is available at

http://dx.doi.org/10.1061/(ASCE)CO.1943-7862.0000811

Copyright American Society of Civil Engineers 


\section{SURVIVAL FACTORS FOR SUBCONTRACTORS IN ECONOMIC DOWNTURNS}

2 Ricardo J. Oviedo-Haito ${ }^{1}$

3 Jaime Jiménez ${ }^{2}$

4 Francisco F. Cardoso

$5 \quad$ Eugenio Pellicer ${ }^{4}$

6

$7 \quad{ }^{1}$ Ph.D. Candidate, Departamento de Engenharia de Construção Civil, Universidade de São Paulo, Av.

8 Prof. Almeida Prado 2-83, São Paulo, Brazil, tel.: +55.11.3091.5469, email: mltca1@yahoo.com

$9{ }^{2}$ Part Time Professor (Ph.D.), School of Civil Engineering, Universitat Politècnica de València, Camino

10 de Vera sn, 46022 Valencia, Spain, tel.: +34.963.879.562, email: jaijiay@cst.upv.es

$11{ }^{3}$ Professor (Ph.D.), Departamento de Engenharia de Construção Civil, Universidade de São Paulo, Av.

Prof. Almeida Prado 2-83, São Paulo, Brazil, tel.: +55.11.3091.5469, email:

francisco.cardoso@poli.usp.br

${ }^{4}$ Corresponding Author. Associate Professor (Ph.D.), School of Civil Engineering, Universitat

Politècnica de València, Camino de Vera sn, 46022 Valencia, Spain, tel.: +34.963.879.562, email:

pellicer@upv.es

\section{ABSTRACT}

This paper analyzes key issues facing subcontractors in the context of a severe economic crisis, aiming to detect the factors that are critical for the survival of the subcontractors. While previous research efforts have analyzed factors related to subcontractor performance in regular financial conditions, there remains only sparse knowledge of how subcontractors are to survive when economic conditions become dire as they have in recent times in the Spanish construction market. In 
this research, in-depth interviews with managers of relevant Spanish subcontracting companies were carried out, resulting in the identification of eight factors for subcontractor survival: project delivery method, demand, financial capital, relationship assets, managerial assets, human assets, legal framework, and geographic scope. The project delivery method used by the owner and also by the main contractor is mainly based on price. As a result, the subcontractors' bids get lower, making them unsustainable in the long run. Furthermore, subcontractors do not get financial support from banks easily in order to cover their additional financial costs. These facts push subcontractors to get a guarantee of payment by the main contractor, while subcontracting companies may even ask for payments in advance. Subcontractors also seek long-term relationships with the contractor. These trusting relations are very often a prerequisite to qualify and bid for contracts. Subcontractors have to continuously improve, plan ahead and adapt quickly to the new environment. Therefore, subcontractors must remain flexible and maintain a lean hierarchical organization. Doing so makes it is easier for subcontractors to compete in both their native markets, as well as abroad. To this end, the most successful subcontractors have become international during the expansion phase of the economic cycle; many of them went abroad with the help of a contractor from their home country.

KEYWORDS: Construction; Economic Crisis; Spain; Survival Factors; Subcontracting

\section{INTRODUCTION}

A country's economy is significantly influenced by the construction sector, not only because of the construction activities per se, but also because of the related industries that supply equipment and materials, as well as services such as engineering and architectural consultancy, operation activities, and facility management. The significance of the sector is reflected by its relative weight in the Gross 
Domestic Product (GDP): approximately $10 \%$ for the whole European Union (FIEC 2007) and 13\% for Spain in 2006 (SEOPAN 2012). However, the financial crisis of 2007 hit the construction industry heavily (Ichniowski 2012; Villegas et al. 2012). This is especially true for Spain and other Southern European countries, where the sector has seen a $75 \%$ reduction in residential building production, $67 \%$ drop in public procurement, and accounts for approximately $75 \%$ of job losses in Spain, during the 2007-2011 period (SEOPAN 2012). In view of this scenario, the largest Spanish construction companies have increased their production in foreign countries (Martin and Gonzalez 2010; Villegas et al. 2012). Spanish contractors are, after the Chinese, the second most successful worldwide ( $9 \%$ of the total), and the first in Latin America, with a 32\% share of the market (ENR 2012).

61

In the Spanish construction industry, the design-bid-build project delivery method accounts for $75 \%$ of public procurement, whereas the remaining $25 \%$ consists basically of concession contracts (SEOPAN 2012). There are only two types of contracts regarding payment provisions in view of the Spanish Law 03/2011 on Public Contracts: unit-price (according to a bill of quantities) and fixed-price (or lump sum); the former is the more habitual one, whereas the latter is only admissible under strict circumstances (de la Cruz et al. 2006). Even though there is no official data regarding private contracts, the design-bid-build delivery method is used most often because of the regulations imposed by Law 38/1999 on Building and the traditional modus operandi of the industry (Pellicer and Victory 2006); the Law 38/1999 overprotects the architect as an independent professional and deters in fact other alternative delivery methods. Lump-sum and unit price payment provisions are both equally implemented for residential buildings. Only industrial or commercial entrepreneurs use relationship-based or integrated delivery strategies (García-Monsalve 2005). Regarding the procurement procedures, two of them are mainly used by public and private owners: (1) open bid (or low bid), where only the price is considered; and (2) a one-stage request for proposals (RFP), where the price, the technical proposal, the schedule, the quality and safety control 
procedures, and the team experience are the factors generally considered (Pellicer and Victory 2006). When using a one-stage RFP in public contracts, the price is the factor more weighted (at least 50\%) because of requirements imposed by the European Union through Directive 2004/18/EC on the coordination of procedures for the award of public works, supply and service contracts. Furthermore, the two-stage RFP is rarely used by owners. However, private owners sometimes use the pre-qualified bid or sole source procurement strategies.

In this scenario, most of the time contractors are selected based on low price as the main factor of the bid. The owner's project delivery strategy forces the contractors to select subcontractors based on low price too, even though the contract between these two parties is always private from a legal standpoint. Relationships among the different stakeholders (owner, designer, main contractor, and subcontractors) are adversarial, and collaboration is not sought (de la Cruz et al. 2006). Main contractors do not perceive subcontractors as cooperators either (Kumaraswamy and Matthews 2000; Mason 2010). Subcontracting in Spain is regulated by Law 3/2011 on Public Contracts and Law $32 / 2006$ on Subcontracting in Construction. These regulations allow for subcontracting up to a maximum of $60 \%$ of the total turnover of the construction project and for three tiers of subcontracting only, including the self-employed workers in the lower tier.

To a limited extent some research has been done regarding the behavior of the construction industry during recession periods; most of the contributors have developed prediction models for implementation in construction companies. Kangari (1988) analyzes the effect of macroeconomic factors on construction companies' failures comparing different ratios and proposing a model obtained from a multiple regression analysis; later on, this model is tuned up and focused on the company' financial performance (Kangari et al. 1992). A similar approach is followed by Langford et al. (1993) and Abidali and Harris (1995) using multivariate discriminant analysis, and by Hall (1994) using logit regressions instead. Arditi et al. (2000) present an alternative approach grouping the 
causes of failure in view of the environment conditions and the company's response; they conclude that most of the failures are due to budgetary and macroeconomic reasons. Later contributions deal with the specificities of the Asian economic crisis of the late twentieth century in Hong-Kong (Chan et al. 2005) and Korea (You and Zi 2007). Lim et al. (2010) also deal with the Asian economic crisis in Singapore through a survey that provides an in-depth analysis of the survival strategies used by contractors. Finally, Jung et al. (2012) evaluate the international performance of Korean contractors over a complete cycle of expansion-contraction-expansion. These two last contributions are somehow contradictory in their main implications: whereas the former claims that main contractors should stick to its basic business, the latter proposes an international diversification strategy; both papers, however, highlight the importance of financial soundness for the survival of the firms.

The above contributions have broadened the body of knowledge on the behavior of the construction industry during economic downturns. Nevertheless, these studies are focused on the behavior and performance of the main contractors, in particular, or on the construction industry, in general. Moreover, some authors have analyzed subcontracting companies using different approaches, as it will be seen in the following section, but none of them has approached their performance in an economic crisis scenario. In this competitive market of very low demand and high supply, contractors and subcontractors have to adapt to the new environment (Villegas et al. 2012).

Therefore, the purpose of this paper is to analyze the issues facing subcontractors in this scenario of severe economic crisis, and the study aims to detect the factors that are critical for these companies to survive. The research question can be stated as follows: What are the factors facilitating the survival of subcontractors in a scenario of severe economic crisis? The research involved in-depth interviews with managers of relevant subcontracting companies; all the subcontractors are still in business and they have good reputations in the industry. In the following sections, we will discuss the relevant literature, describe the research method, and explain the results (survival factors); the 
discussion includes references that support arguments, as well as counter-references, and direct quotes from the interviewees in order to enrich the argument. Finally, the main contributions of the research, its managerial implications, and the future lines or research are drawn in the Conclusions section.

\section{LITERATURE BACKGROUND}

Subcontracting is defined as the outsourcing of the tasks that differ the most from the main activity of the contractor; these tasks are awarded to other companies named subcontractors, which supply materials, equipment and manpower (González-Díaz et al. 2000; Yik and Lai 2008; Ng et al. 2009; Tam et al. 2011). The supply chain has several tiers (or layers) of outsourcing: companies that work directly for the main contractor (top-tier), and companies that work for the former (low-tier or subsubcontractors); there may be additional tiers of sub-subcontractors until reaching the lowest tier of self-employed workers (Yik and Lai 2008). Thus, the supply chain becomes a multi-tier subcontracting system (Choudry et al. 2012).

Because of the uneven demand of the construction sector (Winch 1998; Tam et al. 2011), subcontracting allows the main contractor to transfer the risk to the subcontractor, in cascade subsequently in the supply chain (Beardsworth et al. 1988; Hsieh 1997; Ng et al. 2009; Choudry et al. 2012). This transfer of risk takes into consideration the workload pressures and resources constraints, as well as financial profits (Beardsworth et al. 1988; Ng et al. 2009). The main contractor avoids hiring all the planned resources (workforce, plant, equipment) to carry out the project awarded (Choudry et al. 2012). The main contractor (and top-tier subcontractors, too) reduce their overhead costs and retain fewer full-time workers. Other risks, such as errors in estimating or 
additional payments to the workforce (over time or insurance), are also transferred to the subcontractor (Loh and Ofori 2000).

157

Division of labor increases operative efficiency of the construction project, adding as many tiers of subcontracting as required by the magnitude and difficulty of the project (Elazouni and Metwally 2000; Arditi and Chotibhongs 2005; Tam et al. 2011). Given the specialization and experience provided by subcontractors (Hinze and Tracey 1994; Choudry et al. 2012), subcontracting also introduces the main contractor to other geographical markets, increasing the efficiency in projects by using local subcontractors (González-Díaz et al. 2000). Overall, subcontracting increases flexibility, making the whole supply chain system more resilient (Winch 1998; Yik and Lai 2008; Zou and Lim 2006).

There are, however, a series of problems created with subcontracting. Low-tier subcontractors use cheaper labor, equipment and materials (Low and Sua 2000; Tam et al. 2011); this means poor business practices and performance (Schaufelberger 2003; Yik and Lai 2008; Ng et al. 2009; Tam et al. 2011) and a final product of low quality (Elazouni and Metwally 2000; Tam et al. 2011; Choudry et al. 2012). Some authors blame this bad performance on the conflicts and risks that are pushed down the hierarchy from the main contractor to subcontractors, leading to antagonistic and contentious relationships (Hinze and Tracey 1994; Kumaraswamy and Matthews 2000; Eom et al. 2008).

The growing number of firms involved in the process makes communication throughout the supply chain particularly inefficient (Yik and Lai 2008; Choudry et al. 2012). Thus, there is an additional need to coordinate and control (Elazouni and Metwally 2000; Tam et al. 2000) in order to somehow neutralize the reduction of overhead costs mentioned earlier. By accepting risk from the main contractors, the subcontractors are more vulnerable to market fluctuation, especially the low-tier firms (Schaufelberger 2003; Ng et al. 2009; Yik and Lai 2008). In many countries, there is no specific 
regulation on subcontracting in general, nor is there a legal framework for formal contracts between the different companies in the supply chain (Yik and Lai 2008; Choudry et al. 2012). All this hinders the accountability among the parties when problems appear (Hinze and Tracey 1994; Choudry et al. 2012)

Subcontracting is a worldwide practice in the construction industry. Specific reports have been published about subcontracting in countries such as the United States (Hinze and Tracey 1994; Arditi and Chotibhongs 2005), Hong Kong (Yik and Lai 2008; Ng et al. 2009; Tam et al. 2011), Taiwan (Hsieh 1998), the United Kingdom (Winch 1998; Briscoe and Dainty 2005), Pakistan (Choudry et al. 2012), Japan (Reeves 2002), Brazil (Oviedo-Haito 2010), Australia (Zou and Lim 2006), or Spain (GonzálezDíaz 2000), to cite a few. In spite of being a universal modus operandi, subcontracting depends on the construction culture and specific regulations of each country.

\section{RESEARCH METHOD}

The grounded theory method (Glaser 1978 and 2002; Charmaz 2006) was chosen for this study, which aims to find out the factors facilitating the survival of subcontractors in a scenario of severe economic crisis. The research explained in this paper does not require developing a theory; nevertheless, the concept-indicator model (Glaser 1978) was used to systematically collect, codify and compare the emerging categories found. This research is exploratory in its nature. The data was collected through in-depth open-ended interviews (Woodside 2010).

The sample criteria to select the interviewees were established in the following way. In a previous research developed by one of the authors regarding the implementation of project management practices by Spanish contractors (Sutrisna et al. 2012), 12 contractors were investigated; this sample 
included three large companies (with annual turnover above 2.5 billion Euros) and nine medium companies (with annual turnover between 75 and 400 million Euros). The interviewees (senior managers and heads of departments from these main contractors) had to provide a short-list of reliable subcontractors per sub-fields. Out of a list of more than 50 subcontractors, 12 of them were chosen considering their preference among the main contractors and their accessibility (the subcontractors had to agree to participate in the research).

Another target was to cover all the main sub-fields or trades within a construction project in order to guarantee a minimum homogeneity among participants. Every firm analyzed included labor among its outsourced resources, and had a minimum annual turnover of two million Euros and ten full-time workers. Furthermore, the interviewees are senior managers of subcontracting companies with a minimum of ten years of experience.

The sample size was obtained by theoretical saturation (Glaser 1978 and 2002; Charmaz 2006). According to Guest et al. (2009), if there is homogeneity in the sample, saturation is achieved between the eighth and twelfth interview. In this research, it was attained after the eighth interview too. Four additional interviews were conducted as means of confirmation, but they brought very little new information to the aggregate findings. The 12 interviewees and their corresponding companies are described in Table 1. The companies are classified according to the service offered, experience, workforce, turnover, and size; the size of the company is obtained according to the business turnover of the company only (European Commission 2003), as follows (see Table 1): (S) less than 10 million Euros; (M) between 10 and 50 million Euros; and (G) over 50 million Euros.

The data were collected with a protocol that used relevant questions to be followed during the interview. It also complied with the usual characteristics of long interviews, as described by Woodside (2010). This guided questionnaire had two main parts: one characterizing the company 
and the interviewee (Table 1), and the other describing the value chain and its interaction with the environment. Given the exploratory approach of the study, deviation from the issue at hand was allowed by the interviewer when other topics of interest were raised by the interviewees. In this new scenario of economic downturn, it was especially important to determine: (a) if the firm had to adapt somehow in order to survive; and (b) what issues were more relevant for the survival of the firm. Knowledge acquired this way was brought up in subsequent interviews to determine if it was just an individual opinion or one of general consensus. The whole procedure took around three hours per interviewee. The collected data was transcribed, read again, and organized. After a second reading, it was subjected to coding procedures. A final reading led to writing the memos; these memos take the researcher from data to conceptualization, determining the core categories (Charmaz 2006). These categories were constantly compared with data coming from new interviews, as well as from the literature review, using triangulation until saturation (Charmaz 2006). This protocol allowed core categories to emerge and explain theoretically how the phenomenon under study works (Glaser 2002; Charmaz 2006).

$<$ TABLE 1 HERE $>$

\section{RESULTS AND DISCUSSION}

252

Even though the final aim of the research process was to identify the core categories, their explanation and justification followed a reverse logic. First, the core categories obtained as a final output of the research were stated, and later they were justified and analyzed thoroughly. From the interviews, many indicators were identified and they were coded as 34 factors or subcategories; they were grouped into eight final categories: financial capital, legal framework, demand, geographic 
scope, project delivery system, managerial assets, human assets, and relationship assets. Table 2 describes the set of 34 subcontractor survival factors for each one of these core categories.

$<$ TABLE 2 HERE $>$

262

As stated in the previous section, it was important to determine the factors that were especially relevant for the survival of the firm in an economic downturn. Table 2 highlights in bold those factors that facilitate the survival of subcontractors in a scenario of severe economic crisis from those factors that allow the survival or success of a subcontractor in any stage of the economic cycle (sometimes simply making more profit). Nine out of 34 factors, representing five out of eight core categories, are specifically relevant in economic downturns. The other 25 factors can be considered valid for any economic situation. Several authors (Schleifer 1990; Hall 1994; Arditi et al. 2000; Lim et al. 2010) have already considered some of these general factors for contractors. Their contributions are taken into consideration later in the discussion in order to: (a) differentiate between general and specific factors; and (b) support (or not) the opinions of the interviewees.

273

The survival factors obtained through this research are explained, analyzed and justified, per group of categories, in the following sub-sections. References supporting these factors, as well as some counter-references, are also included in the discussion. Furthermore, comments from the interviewees (verbatim) enrich the argument; each quotation is referred to the corresponding interviewee in parentheses according to Table 1. The process of analysis and comparison of direct quotes and references supporting evidence lead to the final factors listed in Table 2. 
During the expansion phase of an economic cycle, subcontractors are driven by each contract's profitability measured as profit from sales ( $\mathrm{Ng}$ et al. 2009). However, in the current crisis environment, mistrust increases along with the risks, producing shortages and higher costs of interest, thus hampering subcontractors' access to credits and affecting their profit margin directly (Wood and Ellis 2005). Crisis scenarios also favor opportunistic behaviors in agents of the construction industry, mostly in general contractors (Arditi and Chotibhongs 2005). For their own profit, they impose conditions with their bargaining power, encouraging market malpractices, e.g. contractors finance the project based on deferred payments to subcontractors (Mason 2010): "Banks, in their distrust, do not lend us money to finance our operation as subcontractors; we have waiting periods as long as 270 days to receive progress payments from our clients" (E8).

Having credit becomes a key factor from the moment that subcontractors must pay for materials in advance, equipment and manpower sent to the building site (Schleifer 1990; Ng et al. 2009). Their recovery period is much longer than their payment period, especially since the workers' wages are paid within 30 days (Arditi et al. 2000). By assuming the additional financial cost, subcontractors need additional financial support (Arditi and Chotibhongs 2005). The problem is more serious when banks restrict their credit policies.

While in good times subcontractors could afford to increase prices with additional financial costs (Arditi and Chotibhongs 2005), nowadays the insolvency of contractors and banks' loss of confidence has made subcontractors' situations far more critical (Yik and Lai 2008): "I am not a bank and I have no ability to finance the work of my clients" (E2). Now it is essential for subcontractors to make a preliminary selection of clients, and carefully analyze the payment method ( $\mathrm{Ng}$ et al. 2009). Specifically, they try to avoid being paid by promissory notes because if the subcontractor deducts them and in the end the client does not pay, the bank will charge the amount due plus interest to the subcontractor (Arditi and Chotibhongs 2005). 
Companies that were more aware of the financial risk, or those that were able to change the focus in time, have managed to stay successful in this new scenario (Schleifer 1990): "For me the priority has always been to get paid; otherwise, I cannot pay my workers' wages" (E6). In these conditions, it is essential "to be financially sound to work" (E4). Any dysfunction in the capital market may be amplified and subcontractors feel it deeply (Chiang 2009): "Banks have closed the credit tap; there is lack of cash flow in financial markets" (E6). The problem is that banks lack the confidence to lend to any business related to the construction sector, even for those subcontractors who have always met their financial obligations; that were not the case during the expansion phase (Arditi et al 2000).

Shortly before the start of the crisis, hardly anyone cared about the payment method and most only negotiated the maturity of the payment document ( $\mathrm{Ng}$ et al. 2009). The situation has changed dramatically: "I only accept contracts if I'm paid with confirmation or endorsement; if not, I have to assume too much risk" (E11). More and more subcontractors are now under a debt renegotiation process with their clients, and many of them were quick to point out: "The possibilities of us getting paid are minimal; we have given up on that money, or at least the majority of it" (E10). Another interviewee stated that "at this moment, we cannot increase investment in new machinery and equipment" (E8).

\section{Legal Framework}

The existence of a well-established and consolidated legal framework forces subcontractors to continuously improve (Sese et al. 2002). Since the approval of Spanish Law 31/1995 on Occupational Risk Prevention, safety conditions on building sites have also significantly gotten better (Rubio et al. 2008). This has been an opportunity for many companies which once bet on this strategy. This makes it easier for them to compete in their home market, and also when they decide to go abroad. 
There is widespread agreement among the interviewees that legal compliance has helped them enhance their businesses: "The law on subcontracting has helped remove many commission agents that were not really companies at all" (E2). However, other authors (Tam et al. 2011) indicate that this increasing compliance with the law is not a general rule worldwide.

The existence of sector agreements that ensure guarantees for workers in the construction sector has had not only a severe impact on wages, but it has also brought improvements in risk prevention and training: "We cannot have unskilled laborers working at sites except to do very basic and lowrisk tasks" (E1 and E12). In this scenario, companies prefer to train these workers so they can perform as skilled workers.

However, there are still shady aspects that the legal framework has failed to change, despite the various regulations issued. The main one is the regulation of payment to subcontractors, with the late payments as the most relevant example. Even though the deadline for payments is established in 60 days, "typically, you're offered payments delays between 180 and 210 days; the problem is that if I don't accept these conditions, there are many other companies that are willing to do so" (E3 and E8). In any event, general contractors claim that public agencies do not meet their payment obligations either.

\section{Demand}

In a crisis scenario, there is a clear downward pressure on costs from the demand side. The downstroke of prices is not sustainable in the long run: "To apply a discount is an option that can be taken very easily" (E8). This can lead more professionalized companies into a difficult situation if they are continuously selling below cost (Schleifer 1990; Arditi et al. 2000; Lim et al. 2010), 
consciously or unconsciously: "Clients always want the cheapest" (E5). This stereotype must be broken for the mutual interest of all parties.

362

This question is particularly critical for bidders with less differentiation in their trade (Dainty et al. 2001): "Our clients are not willing to pay more for the differences in our bids" (E6). It is therefore necessary to continue looking for distinguishing characteristics which are valuable for the client even in a crisis scenario; characteristics which were differential five years ago are no longer. Once this problem is detected, subcontractors must find a way to escape this spiral which is very dangerous for firms: "We are trying to make new valuable proposals to access the market segments that had not been reached previously" (E5).

At the peak of the crisis, all the interviewed subcontractors met the requirements of the market. Even some subcontractors consider that being hired through price bids is positive: "It forces us to keep up and pay attention to changes in the market and our competitors" (E10). Thus, it seems much more productive to have a proactive attitude to changes in demand: "We are now recruiting through fixed-term work contracts to cover peak demand for labor" (E10). This challenges the typical defeatist attitude that eventually leads to the failure of the company: "There is much uncertainty, poor and very poorly paid work" (E9).

Another of the most common inefficiencies arising on the demand side is that contractors work throughout the whole process regardless of all the interference between the activities carried out by different subcontractors. Those tasks left in no man's land finally generate unforeseen cost overruns for the contractor. The subcontractor makes a profit in the short-term out of these "unexpected events". But the successful subcontractor that establishes long-term relationships with clients is the one who can warn the contractor of future problems and, at the same time, include these 
contingencies in the bid. These gaps between different tasks affect not just the construction phase, but also the design phase and then have implications in the operational phase of the project as well.

\section{Geographic Scope}

Subcontractors that are performing best during the crisis scenario have also adapted their geographical scope. The most pronounced trend is internationalization. In general, all stakeholders in the production chain (developers, construction companies, engineers, subcontractors and suppliers) have considered extending their scope (Martin and Gonzalez 2010). Local companies have broadened their scope to the whole country and the larger ones have become international (Schleifer 1990; Jung et al. 2010 and 2012), the difference being the period cycle in which companies have taken this decision. It is not the same to become international as a long-term strategy (during the expansion phase of the cycle, mainly) than it is to work based on short-term need (economic contraction cycle).

A very particular behavior pattern in subcontractors is to go abroad with the help of a compatriot contractor (Arditi et al. 2000); this way, subcontractors try to spread their risks on a larger portfolio of projects to limit the risks associated with country-specific issues (Jung et al. 2010): "We are wellknown in Spain and so they trust us abroad" (E7). Those who have not yet taken the step of internationalization are conscious that this is the best way: "I am currently making international bids for my best customer" (E11). However if the proposal to go abroad comes from unknown companies, the response is different: "I have had proposals to work abroad, but they did not seem reliable enough" (E3). Jung et al. (2010) also found that this pattern is not usually successful and other authors considered that expansion beyond the capabilities of the firm might be unwise (Schleifer 1990; Arditi et al. 2000; Lim et al. 2010). The decision to internationalize is even more 
complex if the subcontractor's activity requires substantial investment in equipment: "I will only invest abroad if I have secured contracts with a client I know well" (E6).

Project Delivery Method

414

Contractors tend to make the final decision to award a contract primarily based on the bid price (Arditi et al. 2000; Kumaraswamy and Matthews 2000). They are not willing to pay a higher price for the higher quality that subcontractors often wield in their sales pitches (Tam et al. 2011). However, the key factor for many successful subcontractors is that they are able to offer extras that add value and that the contractor can transfer to his client, generating a win-win scenario (Eom et al. 2008). Ultimately, this helps to improve the contractual relationship between them.

The main contractor's bargaining power can also be applied to transfer the risks the company takes in its contract with its client through clauses in the subcontracts (Dainty et al. 2001); hence, the subcontractor can do little to minimize the risks transferred to him. The contractual relationship between contractor and subcontractor is always subject to the lack of bargaining power of the latter towards his client (Hinze and Tracey 1994; Chiang 2009). This is exacerbated when similar bids can be found between different subcontractors (Reeves 2002). The key to differentiation and to gain a better bargaining position lies in the subcontractor's ability to differentiate his product by adding a good dose of services to facilitate his client's work (Gonzalez-Diaz et al. 2000; Dainty et al. 2001). Ng et al. (2009) claimed that managerial skills of subcontractors influence the awarding decision of the main contractor; however, the findings of this research do not support this claim. Further, in a crisis scenario it is more difficult to overcome the lack of bargaining power, and the contractor reinforces his position bringing prices down (Hinze and Tracey 1994; Arditi and Chotibhongs 2005): "They take advantage of the situation asking us for contractual guarantees of about $5 \%$ of the contract, and 
they hold them longer than they should" (E11). In this scenario, bid-shopping is very frequently the norm (Hinze and Tracey 1994; Arditi and Chotibhongs 2005).

437

When the infrastructure life cycle follows the separate stages of the traditional design-bid-build sequence, usually integration problems appear in the project too. This is because the knowledge of previous stages is not incorporated in the later ones, causing uncertainties in the final product and inefficiencies in the execution (Kumaraswamy and Matthews 2000; Dainty et al. 2001). All this leads to poorly defined projects (Arditi et al. 2000); therefore, the ability of some subcontractors to work hand-in-hand with their clients to solve these problems with mutual benefit, is a competitive advantage (Ng et al. 2009). For other subcontractors, their lack of design skills is a source of conflict with the main contractor. It is not simply a question of transferring risks to the subcontractor, copying the clauses that bind the contractor with the owner: it is about considering the subcontractor as a collaborator (Dainty et al. 2001).

Major contractors often ask for several versions of bids, extending the selection period of subcontractors. The problem is to the contractor's disadvantage: "When you are awarded the contract, you have to start the very next day and you always begin with a delay" (E3). The ability to react quickly is not common to all subcontractors, yet it is highly valued by their clients (Kumaraswamy and Matthews 2000; Dainty et al. 2001). The lack of agreement on the start date frequently spreads to the whole works schedule. Therefore, the scheduling of the project is not usually negotiated, but rather imposed by the contractor; the subcontractor simply complies with it without any possibility of adapting it at his discretion (Eom et al. 2008).

457 
Subcontractors do not usually follow a systematic management process at their construction sites.

461 For example, among the interviewed companies, only one is certified in processes (ISO 9001, ISO 14001 and OSHAS 18001), whereas five are only certified in product quality; the rest of them do not have any certification of this kind. Furthermore, all the subcontractors stated that flexibility is one of their main competitive advantages in business management: "We have the flexibility to revert our organization to the 2007 scenario very quickly, even tomorrow" (E10). Such statements are possible because subcontractors are small businesses with an organization completely centralized in the owner or CEO (Arditi et al. 2000).

In this case, the entire management process of the company is determined by the personality of the founder, rather than by training, which is rarely college level (Schaufelberger, 2003). In these companies, the first step towards professionalizing management is taken in finance and accounting: "Our priority is to bring an analytical accounting system that would allow us to obtain economic data contract by contract" (E2). In fact, before taking this step, subcontractors usually outsource financial management and accounting services through small financial and economic consulting firms. As subcontractors are progressing professionally, they require more and more information and communication tools (Hall 1994), as well as administrative software (Schleifer 1990). However, only large subcontracting companies use Enterprise Resource Planning packages.

\section{Human Assets}

Human assets are undoubtedly of major importance for businesses nowadays. It has even become an advertising slogan for many companies, by dint of being repeated by human resources and marketing departments. But subcontractor companies are labor intensive, focusing on manual work, and they require skills that are acquired almost exclusively from practice ( $\mathrm{Ng}$ et al. 2009); in this scenario, human assets are critical (Hall 1994; Eom et al. 2008). The subcontractor's site manager is a 
key agent who assures the progress of the works, as well as the subcontractor's profit.

Subcontractors have a great capacity to adapt to the characteristics of each contract, being very flexible when expanding or reducing their workforce. In many cases, the subcontractor' site manager assumes as well the role of a supervisor or foreman for the main contractor (Hinze and Tracey 1994).

490

During the current recession there have been two different stages in regard to workers dismissal. In the first stages companies got rid of surplus and less trained personnel (Lim et al. 2010): "The only good thing about the crisis is that the less productive workers are no longer in the company" (E2); another interviewee said that "workers now work only according to their skills, and if they are unskilled they are unemployed" (E7). In the second stage the dismissals affect key personnel of the organization, jeopardizing the competitiveness of the company (Schleifer 1990): "Now is a time when we are taking up early retirements for more experience manpower" (E3). Interviewees agree that companies are struggling to keep construction managers and foremen on staff, especially those who have better knowledge of the activity: "We seek contracts just to keep our best workers" (E5).

500

This surplus of professionals in the market means lower labor costs, and companies that have adjusted their staff do not have any problems to meet peak demand: "Now manpower is not a problem, there is a greater deal of unemployment and you can find workers immediately" (E12). Although the paradox is that there are workers who prefer staying unemployed rather than working for a month: "They find it more profitable to collect the unemployment subsidy from the Government than to stop receiving it to work occasionally" (E9).

507

All the interviewees recognized the importance of skills and the loyalty of the workforce and the technical staff (Hall 1994; Ng et al. 2009): "All our workers, in addition to experience, have studied and they keep on doing so today" (E12). However, not every company solves its training needs in the same way. Larger companies have training departments with annual budgets to train all levels of 
staff, from laborers to senior management: "We take all available grants, and also invest equity in training" (E1). In contrast to the dominant model that focuses on internal training (Choudry et al. 2012), there are others who prefer to recruit experienced professionals, who work independently right away: "With current market prices, I cannot spend money on training a worker" (E11).

516

517 On certain occasions, during the expansive economic cycle, companies were faced with the opposite scenario. There was a great lack of personnel with suitable training and experience. Thus, contractors, unable to recruit or retain their managers or supervisors, had to rely on the subcontractors' foremen and supervisors to perform this role. This has been useful for many subcontractors who have known their clients "from the inside" and taken advantage of it during the crisis.

It is still common to find on-site supervisors or foremen with substantial experience but little formal training. However, there seems to be a trend to increasingly appreciate formal training. The increasing specialization of work, depending on the job category of each worker, is leading to a growing demand for training and a greater appreciation of it.

Despite the acknowledged ability of subcontractors to accommodate peak demand in contracts, as they have a flexible workforce, more professionalized subcontractors have in recent years bet on mechanization ( $\mathrm{Ng}$ et al. 2009). This trend has been most pronounced in jobs that require more physical exertion, by introducing more elevation and transport machinery at building sites. Investment in equipment by certain subcontractors has improved competitiveness as wage costs of direct labor have increased (Chiang 2009).

But the most remarkable aspect in regard to human assets is that the more qualified personnel, once aware of the current situation, begin looking for their own niche in the labor market, either in other 
sectors or in other countries. This is causing an accelerated drain of skilled and knowledge-intensive personnel in the construction industry. Employees who were emigrants employed in the industry are now returning to their home countries because they are finding better conditions there: "Others are going on an adventure to countries where they have relatives or simply acquaintances that can offer them a job" (E7).

\section{Relationship Assets}

A subcontractor's corporate image, the relationships of trust established in the sector (Kumaraswamy and Matthews 2000; Kale and Arditi 2001), and the existence of previous links with the main contractor are key issues to obtain new contracts (Yik and Lai 2008; Ng et al. 2009; Zou and Lim 2006). This partially contradicts the main factor highlighted in the project-delivery-method category: that price is the decisive factor when awarding a subcontract (Lim et al. 2010). So, these "trusting relationships" could be considered as a prerequisite to qualify and bid for contracts.

The ability of subcontractors to keep up-to-date through their professional network is yet another key factor underlying their success. These relational ties are maintained both in the informal and formal sphere (associations, industry groups, professional lobbies, etc.). Most subcontractors believe that time and resources invested in fostering these relationships are profitable, even though it may be intangible. Lobbying is crucial for main contractors since they obtain some political influence or even legal support to appeal public tenders maintaining anonymity; however, subcontractors seek other objectives in lobbying, mainly related to the provision of services which are more expensive than when accessing individually: "Our professional association helps us to keep our staff updated about technical regulations" (E9). Overall satisfaction by members in associations is high: "It works very well and also keeps us up-to-date on the new products coming to the market" (E10). 
564 When it comes to updating collective agreements for workers, lobbies are also useful to improve bargaining power, especially against the unions. Lobbies usually provide other value-added services, with different degrees of acceptance among its members: "They also have an alert service for tender, but for us it is of little use, since we have a better service supplied by an outside company" (E1). Again, the link between trade unions and subcontractors arises, as it does in the previous discussion on legal framework.

570

Although subcontractors seldom form joint ventures, they benefit from the main contractor's jointventures (Arditi et al. 2000). Normally it is one of the members of the consortium who proposes a particular subcontractor to do certain work. Working for the joint venture is an excellent opportunity

574 for the other contractors to know first-hand the capabilities of the subcontractor, and thus, the 575 subcontractor makes a valuable commercial work to attract a new client while fulfilling their contract.

CONCLUSIONS

580

\section{Main Contributions of the Research}

582

This paper analyzes the issues that subcontractors face in an economic crisis scenario and identifies the factors that are critical for their survival, differentiating those coming from an economic downturn from those that can be found in any stage of the economic cycle. While the contributions of this paper are focused specifically on the crisis scenario, the whole set of factors should be considered in any economic scenario. 
Subcontractors' need for financial soundness increases during periods of economic crisis. The project deliver method used by the owner and also by the main contractor is mainly based on price; therefore the subcontractors' bids keep getting lower being unprofitable and unsustainable in the long run. In this particular crisis this fact is exacerbated by the difficulty of getting financial support from the banks. Hence, it is essential for subcontractors to make a preliminary selection of clients, focusing on the payment guarantee and method.

Successful subcontractors establish long-term relationships with their clients warning them of the problems they might encounter in the construction process and, at the same time, including these contingencies in their bids. In spite of the trend to award contracts to the lowest bidder, subcontractors are able to offer value, generating a win-win deal with the general contractor. Ultimately, this helps to improve their contractual relationship.

Regarding the human assets, subcontractors tend to lay off workers according to their (inferior) training, experience, and productivity, not only the employee's cost of dismissal. This is due to the fact that a skilful and loyal core workforce and technical staff are basic for the survival of the firm. Moreover, the surplus of professionals in the construction market allows for a decrease in labor costs. However, qualified personnel, once aware of the current situation, look for their own niche in the labor market, either in other sectors or other countries.

The most successful subcontractors became internationalized during the expansion phase of the cycle, while many others have been forced to do so out of necessity. Furthermore, in an effort to limit risks, these subcontractors have often gone abroad thanks to one of their regular contractors in their home country.

\section{Managerial Implications}


616 After several years of severe crisis in the construction sector, unprofessional and opportunistic 617 subcontractors are out of the market. Therefore, most of the existing companies present at least some of the features described in this research. However, if they do not keep updating their survival is at risk. In order to guide companies, four key managerial implications are briefly explained next: financial soundness, relationships with main contractors, flexibility, and a lean hierarchical organization. In every crisis it is important for the companies to have liquidity; in this particular one, it is even more important because the banks do not lend money easily. Therefore, subcontractors should prioritize their financial health above anything else.

Flexibility is another competitive advantage for the best subcontractors. Subcontractors have to adapt quickly to new scenarios and, if possible, to plan ahead for them. This makes it easier for subcontractors to compete not only in their home market, but also abroad. Subcontractors that invest in their corporate image, build relationships of trust, and that make use of previous links with the main contractor, perform much better than others; these "trusting relationships" can be considered as a prerequisite to qualify and bid for the contracts. Finally, keeping a lean hierarchical organization with a core professional staff skilful and loyal to the company can help the subcontractors to achieve their goal too. The accomplishment of these three additional characteristics can help the subcontractors to attain financial soundness too and, therefore, increase their chance of survival.

Limitations and Future Research

As a final point, the main limitation of this research is that the field work developed was exploratory and the sample chosen was purposive. Even though outcomes cannot be generalized, this research does give insight from top managers of successful Spanish subcontractors in a scenario of severe 
641 economic crisis. The factors obtained in this research should be tested and refined in the future with

642 a larger number of subcontractors, considering time and geographical aspects too. This way, three 643 future research lines are currently open and underway. First, a broader survey of subcontractors 644 would allow generalization to the Spanish scenario of economic crisis. Second, the evolution during 645 the coming years of the twelve companies considered in this research, analyzed as case studies, is being monitored for a comparison between recession and boom periods. Finally, this research is being replicated in Brazil in order to compare subcontractors' behavior in an upward trend scenario with the downward scenario discussed in this paper.

649

\section{ACKNOWLEDGMENTS}

651

This research was partially supported by Santander Universidades (Becas Iberoamérica Jóvenes

Profesionales e Investigadores 2012) that funded a visitorship for Ricardo Oviedo-Haito. The authors are also indebted to all the participants in this research, as well as to Dr. Debra Westall and Dr. Nathaniel Sobin for revising the manuscript. Finally, the valuable commentaries and suggestions of three anonymous reviewers are also highly appreciated.

657

658

Abidali, A.F., and Harris, F. (1995). A methodology for predicting company failure in the construction industry. Construction Management and Economics, 13, 189-196.

Arditi, D., Chotibhongs, R. (2005). Issues in subcontracting practice. Journal of Construction Engineering and Management, 138(8), 866-876.

Arditi, D., Konsal, A., and Kale, S. (2000). Business failures in the construction industry. Engineering, Construction and Architectural Management, 7(2), 120-132. 
Beardsworth, A.D., Keil, E.T., Bresnen, M., and Bryman, A. (1988). Management, transience and subcontracting: the case of the construction site. Journal of Management Studies, 25(6), 603-625.

Briscoe, G., and Dainty, A. (2005). Construction supply chain integration: an elusive goal?. Supply Chain Management: An International Journal, 10(4), 319-326.

Chan, J.K.W., Tam, C.M., and Cheung, R. (2005). Monitoring financial health of contractors at the aftermath of the Asian economic turmoil: a case study in Hong Kong. Construction Management and Economics, 23(5), 451-458.

Charmaz, K.C. (2006). Constructing Grounded Theory: A Practical Guide through Qualitative Analysis. Sage Pub., London.

Chiang, Y.H. (2009). Subcontracting and its ramifications: A survey of the building industry in Hong Kong. International Journal of Project Management, 27, 80-88.

Choudhry, R., Hinze, J., Arshad, M., and Gabriel, H. (2012). Subcontracting practices in the construction industry of Pakistan. Journal of Construction Engineering and Management, 138(12), 1353-1359.

Dainty, A.R.J., Briscoe, G.H., and Millett, S.J. (2001). Subcontractor perspectives on supply chain alliances. Construction Management and Economics, 19, 841-848.

De la Cruz, M.P., del Caño, A., and de la Cruz, E. (2006). Downside risks in construction projects developed by the civil service: the case of Spain. Journal of Construction Engineering and Management, 132(8), 844-852.

Elazouni, A., and Metwally, F. (2000). D-Sub: decision support system for subcontracting construction works. Journal of Construction Engineering and Management, 126(3), 191-200.

ENR (2012). The Top 225 Global Contractors. Engineering News Records (http://enr.construction.com/toplists/Top-Global-Contractors/001-100.asp) (November 21, 2012). 
Eom, C., Yun, S., and Paek, J. (2008). Subcontractor evaluation and management framework for strategic partnering. Journal of Construction Engineering and Management, 134(11), 842851.

European Commission (2003). The New SME Definition. User Guide and Model Declaration. Office for Official Publications of the European Communities, Luxembourg.

FIEC (2007). Annual Report 2006. European Construction Industry Federation, Brussels.

García-Monsalve, J. (2005). El 'project management' aplicado a la construcción. Partida Doble, 164, March, 26-33 (in Spanish).

Glaser, B.G. (1978). Theoretical Sensitivity. Sociology Press, Mill Valley (CA).

Glaser, B.G. (2002). Conceptualization: on theory and theorizing using grounded theory. International Journal of Qualitative Methods, 1(2), 23-38.

González-Díaz, M., Arruñada, B., and Fernández, A. (2000). Causes of subcontracting: evidence from panel data on construction firms. Journal of Economic Behavior \& Organization, 42, 167-187.

Guest, G., Bunce, A., and Johnson, L. (2006) How many interviews are enough? An experiment with data saturation and variability. Field Methods, 18(1), 59-82.

Hall, G. (1994). Factors distinguishing survivors from failures amongst small firms in the UK construction sector. Journal of Management Studies, 31(5), 737-760.

Hinze, J., and Tracey, A. (1994). The contractor-subcontractor relationship: the subcontractor's view. Journal of Construction Engineering and Management, 120(2), 274 - 287.

Hsieh, T.Y. (1997). The economic implications of subcontracting practice on building prefabrication. Automation in Construction, 6, 163-174

Ichniowski, T. (2012). Construction April jobless rate falls, though 2,000 jobs lost nationwide. Engineering News-Record, May 4.

Jung, W., Han, S.H., Park, H., and Kim, D.Y. (2010). Empirical assessment of internationalization strategies for small and medium construction companies. Journal of Construction Engineering and Management, 136(12), 1306-1316. 
Jung, W., Han, S.H., Koo, B., and Jang, W. (2012). Which strategies are more effective for international contractors during boom and recession periods? Journal of Management in Engineering, 28(3), 281-290.

Kale, S., and Arditi, D. (2001). General contractors' relationships with subcontractors: a strategic asset. Construction Management and Economics, 19(5), 541-549.

Kangari, R. (1988). Business failure in construction industry. Journal of Construction Engineering and Management, 114(2), 172-190.

Kangari, R., Farid, F., and Elgharib, H.M. (1992). Financial performance analysis for construction industry. Journal of Construction Engineering and Management, 118(2), 349-361.

Kumaraswamy, M.M., and Matthews, J.D. (2000). Improved subcontractor selection employing partnering principles. Journal of Management in Engineering, 16(3), 47-56.

Langford, D., lyagba, R., Komba, D.M. (1993). Prediction of solvency in construction companies. Construction Management and Economics, 11, 317-325.

Lim, E.T.H., Co, B.L., and Ling, F. (2010).The survival strategies of Singapore contractors in prolonged recession. Engineering, Construction and Architectural Management, 17(4), 387-403.

Loh, W.H., and Ofori, G. (2000). Effect of registration on performance of construction subcontractors in Singapore. Engineering Construction and Architectural Management, 7(1), 29-40.

Low, S.P., and Sua, C.S. (2000). The maintenance of construction safety: riding on ISO 9000 quality management systems. Journal of Quality in Maintenance Engineering, 6(1), 28-44.

Martin, R., and Gonzalez, J. (2010). El reposicionamiento estratégico de las constructoras españolas. Informes de la Construcción, 62, 520, 67-84 (in Spanish).

Mason, J. (2010). Corruption of the commercial process revisited. Construction Law Journal, 26(4), 235-249.

Ng, S.T., Tang, Z., and Palaneeswaran, E. (2009). Factors contributing to the success of equipmentintensive subcontractors in construction. International Journal of Project Management, 27(7), 736-744. 
Oviedo-Haito, R.J.J. (2010). Caracterização das empresas executoras de serviços de obras baseada nos seus ativos estratégicos. M.Sc. Disertation, Escola Politécnica, Universidade de São Paulo, São Paulo (in Portuguese).

Pellicer, E., and Victory, R. (2006). "Implementation of project management principles in Spanish residential developments." International Journal of Strategic Property Management, 10, 233248.

Reeves, K. (2002). Construction business systems in Japan: general contractors and subcontractors. Building Research \& Information, 30(6), 413-424.

Rubio, M.C., Martinez, G., Rubio, J.C., and Ordoñez, J. (2008). Role of the civil engineer as a coordinator of safety and health matters within the construction sector. Journal of Professional Issues in Engineering Education and Practice, 134(2), 152-157.

Schaufelberger, J. (2003). Causes of subcontractor business failure and strategies to prevent failure. Construction Research Congress ASCE, 1-7.

Schleifer, T.C. (1990). Construction Contractors' Survival Guide. Wiley, New York. SEOPAN (2012). Informe Económico 2011. ANCOP, Madrid (in Spanish).

Sese, A., Palmer, A.L., Cajal, B., Montaño, J.J., Jimenez, R., and Llorens, N. (2002). Occupational safety and health in Spain. Journal of Safety Research, 33, 511-525.

Sutrisna, M., Pellicer, E., Picornell, M., and Torres-Machí, C. (2012) Analysing the potential application of the earned value management (EVM) in the Spanish construction industry an initial review of the dataset. In: Vanissorn Vimonsatit, Amarjit Singh, and Siamak Yazdani (Eds.), CPM-15-0257. Research, Development, and Practice in Structural Engineering and Construction, Perth (Australia).

Tam, V.W.Y., Shen, L.Y., and Kong, J.S.Y. (2011). Impacts of multi-layer chain subcontracting on Project management performance. International Journal of Project Management, 29, 108116. 
Villar Mir, J.M. (2009). La crisis económica actual. Sus orígenes y características. Medidas para salir de la crisis. Revista de Obras Públicas, 3496, 19-44 (in Spanish).

Villegas, L., Carrasco, C., Lombillo, I., Liaño, C., and Balbás, J. (2012). Construction in Spain: Crisis 2007-2010 and future prospects. International Journal for Housing Science and Its Applications, 36(2), 109-121.

Winch, G.M. (1998). The growth of self-employment in British construction. Construction Management and Economics, 16(5), 531-542.

Wood, G.D., and Ellis, R.C.T. (2005) Main contractors experiences of partnering relationships on UK construction projects. Construction Management and Economics, 23(3), 317-325.

Woodside, A.G. (2010). Case Study Research. Theory, Methods and Practice. Emerald, Bingley (United Kingdom).

Yik, F.W.H., and Lai, J.H.K. (2008). Multilayer subcontracting of specialist works in buildings in Hong Kong. International Journal of Project Management, 26, 399-407.

You, T., and Zi, H. (2007). The economic crisis and efficiency change: evidence from the Korean construction industry. Applied Economics, 39, 1833-1842.

Zou, P.X.W., and Lim, B.T.H. (2006). An empirical study in subcontractor selection and long-term alliance relationship between main contractor and subcontractor. International Journal of Construction Management, 6(1), 1-13.

(1) 


\begin{tabular}{|c|c|c|c|c|c|c|}
\hline Interviewee & Main Activity & $\begin{array}{c}\text { Company's } \\
\text { Experience } \\
\text { (Years) }\end{array}$ & $\begin{array}{c}\text { No. } \\
\text { Employees }\end{array}$ & Size & $\begin{array}{l}\text { Interviewee's } \\
\text { Position }\end{array}$ & $\begin{array}{c}\text { Interviewee's } \\
\text { Experience } \\
\text { (Years) }\end{array}$ \\
\hline E1 & $\begin{array}{l}\text { Maintenance of civil infrastructures } \\
\text { and gardening }\end{array}$ & 26 & 200 & M & CEO & 15 \\
\hline E2 & $\begin{array}{l}\text { Reinforced concrete foundations and } \\
\text { structures }\end{array}$ & 12 & 50 & $S$ & Partner & 18 \\
\hline E3 & Industrial painting & 19 & 200 & $M$ & Partner & 18 \\
\hline E4 & $\begin{array}{l}\text { Brickwork, masonry and general } \\
\text { workforce }\end{array}$ & 13 & 150 & $M$ & Site Manager & 11 \\
\hline E5 & Concrete forms & 29 & 200 & L & $\begin{array}{l}\text { Marketing } \\
\text { Director }\end{array}$ & 23 \\
\hline E6 & Reinforcement steel & 26 & 120 & $M$ & CEO & 15 \\
\hline E7 & $\begin{array}{l}\text { Equipment and machinery: general } \\
\text { and transportation }\end{array}$ & 10 & 1100 & L & $\begin{array}{l}\text { Marketing } \\
\text { Director }\end{array}$ & 16 \\
\hline E8 & $\begin{array}{l}\text { Equipment and machinery: cranes } \\
\text { and special vehicles }\end{array}$ & 23 & 45 & $S$ & $\begin{array}{l}\text { Marketing } \\
\text { Director }\end{array}$ & 13 \\
\hline E9 & $\begin{array}{l}\text { Brickwork, masonry and general } \\
\text { workforce }\end{array}$ & 11 & 60 & $M$ & CEO & 19 \\
\hline E10 & $\begin{array}{l}\text { Electric and electronic facilities and } \\
\text { maintenance }\end{array}$ & 15 & 10 & $S$ & CEO & 24 \\
\hline E11 & Earthwork & 51 & 55 & $M$ & CEO & 46 \\
\hline E12 & Hydraulic systems & 6 & 35 & $S$ & CEO & 15 \\
\hline
\end{tabular}

Table 1. Characterization of interviewees (data from December 31, 2012). 


\begin{tabular}{|c|c|}
\hline CATE & $\overline{A C T}$ \\
\hline & $\begin{array}{l}\text { - During the contraction phase of an economic cycle, subcontractors are driven by each client's } \\
\text { guarantee of payment, overshadowing profitability } \\
\text { - During the contraction phase of an economic cycle, subcontractors ask for payments before } \\
\text { beginning work } \\
\text { - Subcontractors assume additional financial costs; they are paid later than the main contractor, } \\
\text { and they have to provide a performance bond for the contract price } \\
\text { - Because subcontractors assume additional financial costs, they require sound financial support } \\
\text { and any change in the financial market affects them to a large extent } \\
\text { - It is difficult for subcontractors to mitigate the risk of the main contractor's default which may } \\
\text { lead to a chain reaction causing the bankruptcy of the subcontractor too }\end{array}$ \\
\hline $\begin{array}{l}\text { LEGAL } \\
\text { FRAMEWORK }\end{array}$ & $\begin{array}{l}\text { - The legal framework affecting occupational health and safety and subcontracting sufficiently } \\
\text { regulates the relations between the main contractor and its subcontractors } \\
\text { - Health and safety regulations as well as trade union agreements are generally enforced by } \\
\text { subcontractors }\end{array}$ \\
\hline DEM & $\begin{array}{l}\text { - During the contraction phase of an economic cycle, competition is among the better and more } \\
\text { specialized firms that survived the peak of the crisis } \\
\text { - The contract can be broken down into work packages by the main contractor without realizing } \\
\text { there are interferences among the different subcontracts } \\
\text { - Subcontractors are rarely involved in the pre-construction phases or in the subsequent operation } \\
\text { phase }\end{array}$ \\
\hline $\begin{array}{l}\text { GEOGRAPHIC } \\
\text { SCOPE }\end{array}$ & $\begin{array}{l}\text { - During the contraction phase of an economic cycle, subcontractors look for contracts abroad } \\
\text { - Subcontractors look for contracts abroad only with the help of regular clients in their home } \\
\text { country }\end{array}$ \\
\hline $\begin{array}{l}\text { PROJECT } \\
\text { DELIVERY } \\
\text { SYSTEM }\end{array}$ & $\begin{array}{l}\text { - The final decision to award a subcontract is taken by the main contractor based essentially on } \\
\text { the price bid } \\
\text { - The main contractor is not willing to pay more for additional quality or reliability that may add } \\
\text { value to the final product or service, unless these extras can be charged directly to the owner } \\
\text { - The main contractor often transfers risks to the subcontractor through clauses in the contract } \\
\text { - Subcontractors' bargaining position is weaker than that of the main contractor, unless the } \\
\text { subcontractor executes highly specialized works } \\
\text { - Subcontractors play a key role in improving projects that start construction with shortcomings } \\
\text { and lack definition, cooperating with the main contractor } \\
\text { - The scheduling of the project is not usually negotiated between main contractor and } \\
\text { subcontractors }\end{array}$ \\
\hline $\begin{array}{l}\text { MANAGERIAL } \\
\text { ASSETS }\end{array}$ & $\begin{array}{l}\text { - Subcontractors do not usually follow a systematic management process in their construction } \\
\text { sites } \\
\text { - It is very common for the subcontracting company to be owned by a single shareholder who } \\
\text { usually manages the company in a very personal way } \\
\text { - The owner of the subcontracting company is both the CEO and the commercial director, } \\
\text { depending on the success of the company and often on his public relations skills } \\
\text { - Subcontractors often outsource administrative, accounting and financial matters to specialized } \\
\text { management firms } \\
\text { - The use of management software by subcontractors is limited to commercial applications (or } \\
\text { slightly customized) for financial accounting }\end{array}$ \\
\hline HUMAN ASSETS & $\begin{array}{l}\text { - The subcontractor's site manager is a key agent for assuring the work progress, as well as the } \\
\text { subcontractor's profit } \\
\text { - Subcontractors have a great capacity to adapt to the characteristics of each contract, being very } \\
\text { flexible expanding or reducing their workforce } \\
\text { - Subcontractors decide to dismiss workers based on training, experience, and productivity, not } \\
\text { only the employee's cost of dismissal } \\
\text { - The training of subcontractors' workers is based more on "learning by doing" than on formal } \\
\text { training, the exception being health and safety regulations } \\
\text { - In many cases, the subcontractor' site manager performs the additional role of a supervisor or } \\
\text { foreman for the main contractor } \\
\text { - Subcontractors have progressively incorporated more equipment to their part of the } \\
\text { construction project, reducing direct labor as human resource costs increase } \\
\text { Due to the long crisis, highly qualified human resources are looking for other kinds of work, in }\end{array}$ \\
\hline
\end{tabular}




\begin{tabular}{lll}
\hline CATEGORY & FACTOR \\
\hline RELATIONSHIP & other sectors, or in other countries, decapitalizing the construction industry \\
ASSETS & $\begin{array}{l}\text { The subcontractor's corporate image, relationships of trust, and previous links between the } \\
\text { main contractor and the subcontractor are a prerequisite to tender a contract }\end{array}$ \\
& - $\begin{array}{l}\text { Subcontractors are increasingly aware of the need to form lobbies to defend their interests as } \\
\text { construction industry agents or looking for technical support } \\
\text { - Subcontractors do not usually form joint ventures with other subcontractors to undertake } \\
\text { greater volumes of work } \\
\text { When a joint venture between construction companies is created, the subcontractor proposed } \\
\text { has an excellent opportunity to expand client portfolio for future contracts }\end{array}$ \\
\hline Note: factors that are specifically relevant in economic downturns are highlighted in bold \\
\hline
\end{tabular}
Table 2. Subcontractor survival factors for core categories. 